Publisher policy allows this work to be made available in this repository. Published in Personnel Review by Emerald. The original publication is available at: https://doi.org/10.1108/PR-01-2015-0002. This article is deposited under the Creative Commons Attribution Non-commercial International Licence 4.0 (CC BY-NC 4.0). Any reuse is allowed in accordance with the terms outlined by the licence (https://creativecommons.org/licenses/by-nc/4.0/). To reuse the AAM for commercial purposes, permission should be sought by contacting permissions@emeraldinsight.com.

\title{
The dynamics of managing people in the diverse cultural and institutional context of
}

\section{Africa}

Ken Kamoche, Lisa Siebers, Aminu Mamman and Aloysius Newenham-Kahindi

\begin{abstract}
Purpose

The purpose of this article is to introduce the special issue which considers some of the contemporary debates in managing people in Africa.
\end{abstract}

\section{Design/methodology/approach}

The papers that constitute this special issue were selected from submissions to various events hosted by the Africa Research Group, a community of scholars committed to researching Africa, and from a more general call for submissions.

\section{Findings}

The papers highlight the changing picture of the African organisational landscape and provide both theoretical and empirical insights about the opportunities and challenges of managing people in a culturally complex continent.

\section{Originality/value}

Taken together, the papers make an important contribution by engaging current debates and demonstrating potential new areas for further research.

\section{Keywords}

Africa, human resource management, culture, leadership 
The management and organisation literature often characterises managing in Africa as 'the challenge of' and rarely do scholars look to the continent for novel ideas, inspiration, best practice, or theoretical insights. Yet, in the last five years or so, the African organisational landscape has witnessed substantial transformation and renewal. While challenges of course remain, we now have a better understanding of the nature, scope and extent of management practices and the role of theory in unpacking these practices than we did a decade ago (e.g. Newenham-Kahindi, et al., 2013). Examples of the emergent literature in specific African countries include the relationship between human resource management (HRM) in Mozambique and business systems theory (Wood et al., 2011), human resource practices in mergers and acquisitions in the Nigerian banking sector (Gomez et al., 2012), cultural influences in small and medium sized enterprises (SMEs) in Kenya (Jackson et al., 2008), the processes of knowledge appropriation amongst foreign banks in Tanzania (Kamoche and Newenham-Kahindi, 2012), and challenges associated with skill shortages and talent management in South Africa (Horwitz, 2013).

This emergent literature highlights the diversity of management approaches, the role of multinational firms, the changing employment relationship, as well as advancing new theoretical insights. Nevertheless, much remains to be done to develop indigenous forms of knowledge which are relevant to Africa and which address the needs of the African labour force. Studies that merely describe and characterise HRM practices, or simply replicate Western studies do little to advance knowledge. The same applies to those studies in which the purpose is to collect African samples with little thought to the unique circumstances of those samples and the context within which they are embedded and from which they derive meaning. A similar phenomenon has been observed in the Asian context whereby the 'exploitation' or 'refinement' of western theories generates only modest contributions to knowledge and does not substantially advance understanding of phenomena in underresearched contexts (Leung, 2009; Li and Tsui, 2002). Scholars engaging organisational phenomena in Africa need to eschew such approaches if we are to gain a deep understanding of the management of people and organisations in the emerging economies of Africa.

We argue that there is a need for a shift in emphasis to foster research that is not only committed to analysing how the diverse African context shapes current thinking and practice in the management of people and organisations (Kamoche et al., 2004), but also how this in turn contributes to the 'mainstream' corpus of knowledge. Hence, scholars need to go beyond 
the topics that have characterised debate so far, for example, comparative analysis of practices at the cross-cultural, cross-sectoral or cross-national levels, the relationship between HRM practices and organisational performance, and so forth. Issues that warrant further attention today include the creation, dissemination and appropriation of knowledge, talent management, human resource capabilities for innovation and entrepreneurship, ethical and strategic leadership, sustainability and business ethics, and the Africa-Asia nexus. These topics have significant implications for the continued creation of a highly skilled African workforce, employment creation and poverty alleviation, the fostering of viable organisations that contribute to economic development, as well as the scope for Africans to realise meaningful benefits from the engagement with foreign investors and multinational firms.

In recent decades, we have witnessed a growing phenomenon of Asian investments in Africa. This has been mostly marked by Chinese firms which have become major players up and down the continent, although Malaysian, Singaporean and Indian firms are also well represented. Chinese investments in Africa stood at $\$ 175$ billion in 2009 and are expected to reach $\$ 300$ billion by 2015 (McMahon, 2011). Much of this investment is channelled through major infrastructural projects such as building of roads, railway lines and ports. A substantial amount has gone into mining, particularly in those countries endowed with oil and other natural resources which are critical for China's rapidly growing economy. The preponderance on the extraction of raw materials has led to criticism that China is only pursuing its selfinterest and that this engagement does little to transform African economies through the creation of sustainable employment. Much of the extant research on this phenomenon focuses on broad macro-economic trends such as the ever-increasing volume of trade, which in fact tends to be mostly one-way, and the international business strategies and approaches pursued by Chinese firms entering the African market.

Serious concerns have been raised about the real benefits of Chinese investments in Africa as this begins to look like a new scramble for Africa (Southall and Melber, 2009; Taylor, 2006). In terms of resource-seeking, it has been suggested that this scramble is less about 'honey pot conflict' than it is a Sino-Western conflict that is self-interest driven and one that is tied to the West's concerns about China playing a 'spoiler' role in Africa (Marton and Matura, 2011). Yet, China's official position is that the engagement is based on the pursuit of a symbiotic relationship. The on-going controversy has engendered a search for new theoretical lenses to characterise this relationship.

An emergent theme is the potential suitability of post-colonial theory in explaining the underpinnings and impact of Chinese investments in Africa, and the implications of a 
pejorative portrayal of African indigenous knowledge and indeed African workers (e.g. Jackson, 2012; Kamoche and Siebers, 2014). For example, the media has reported on incidents of violence towards miners, construction and factory workers in countries such as Zambia, Mozambique and Nigeria. While the true picture is somewhat muddled by the alarmist media reports, it is evident that the influx of Chinese investments into Africa has not been without major concerns. Some of these include widespread abuses and the flouting of employment and labour laws (Akorsu and Cooke, 2011; Baah and Jauch, 2009; Brautigam, 2011). Research in Chinese textiles firms in Kenya has found evidence of employment law violations and sexual abuse (e.g. Opondo, 2009).

Other reports suggest that Chinese firms are making a genuine effort to engage with Africa meaningfully while concerns remain about cross-cultural differences (Kamoche and Siebers, 2014). Following decades of research on the impact of western multinational firms in Africa, attention must now turn to this new Africa-Asia nexus. Equally importantly for our purposes is the need for scholars to focus on how these sorts of engagements, whether they involve western or Asian partners, might be conducted in a manner that is both sustainable and beneficial to African economies and employees, while achieving the strategic objectives of foreign investors. In the sections below, we discuss a number of themes that we believe will increasingly shape debate on the management of people and organisations in Africa, and conclude with a brief summary of the papers presented in this special issue.

\section{Cultural studies in the African context}

In the business and management context, there are multi-faceted dimensions of the bottom-up and top-down relationships, including individual values, group culture, organisational culture, national culture and global culture (Leung et al., 2005). In the past decade, studies on culture and cultural aspects have been tied to issues such as leadership (e.g. House et al., 2004; Walumbwa et al. 2005; 2011; Nkomo, 2011), gaining competitive advantage (Mangaliso, 2001), cross-cultural management (Jackson et al., 2008), and international management (Jackson, 2013). These works have largely been a response to the phenomenon that the African continent was often seen as a homogenous entity. To some extent, these studies raised concerns about the relative neglect of different cultures and cultural values in the very heterogeneous Africa.

There is also an increasing number of studies that highlight the cultural diversity for example in specific African countries, such as Kenya (Walumbwa et al., 2005; Gray et al., 
2008; Jackson et al., 2008), South Africa (Mangaliso, 2001; Valchev et al., 2013), Angola (Oyebade, 2007), Uganda (Khayesi and George, 2011), and Nigeria (Smith, 2013). Nevertheless, there is further scope to investigate more extensively the dynamics of culture in the processes of convergence and divergence in an increasingly globalised Africa. Culture manifests itself in various levels and domains in a way that some cultural elements are stable, whereas others are dynamic (Leung et al., 2005). A recent study by Yousfi (2014) shows that cultural references substantially influence the hybridisation management processes of foreign firms in Africa, such that the former colonial experiences and local cultural context impact on the importation of western management practices. We therefore see a need for further research that captures the complexity of the African cultural context and how this context facilitates or impedes the creation and adaption of management practices, be they indigenous or foreign.

\section{The national, organisational and individual levels of culture}

The extant studies on cultural issues in Africa tend to be located within the context of national culture. A good example is Ubuntu which has been applied as a philosophy and a basis to analyse cultural characteristics in Southern Africa, such as South Africa and Zimbabwe (see Ramose, 2003). Other well-known cultural studies such as the works of Hofstede (1980; 1983) and Schwartz and Bardi (2001) have largely neglected Africa's diversity and tended to treat African countries as aggregated regions. For instance, Hofstede's (1983) investigation into the influence of national culture on work-related values and attitudes treated several African countries as 'clusters'. 'Global' studies also tend to take a small number of African countries which are assumed to be representative of the continent. Schwartz and Bardi (2001) obtained samples from 62 countries worldwide to analyse value hierarchies across cultures but only included four African countries. The impact of a more integrated analysis combining various individual countries in Africa on these cross-cultural business and management studies is not being fully realized.

One of the purposes of this special issue is to advance our understanding of the impact of culture on the effectiveness of business and management in Africa. We expect to draw particular attention to various levels of a cultural perspective (i.e. the national level, the organisational level and the individual level) and their relationship to values, behaviours, attitudes and performance at workplace. Specifically, it is important to examine how individuals and groups are influenced by, and in turn shape the complexity of the diverse 
cultures at work. The African worker's sense of belonging within foreign firms may have a significant influence on the way they define their organisational identity and represent the organisation to outsiders in the society as a whole. Thus, we urge researchers to seek a better understanding of the effect of national culture and organisational culture on individual employees' work values, attitudes and behaviours, as well as on leadership, strategic business alliances and international management.

\section{Cultural impacts on FDI in Africa with Chinese investments as an example}

Given that African countries have started to attract an increasing amount of foreign investments not only from the western countries but also from large emerging economies (e.g. China and India), the dynamics of the cross-cultural elements being developed in Africa may help to form new firm competences in the international business (IB) context (Johnson et al., 2006). Thus, the links between the cross-cultural elements (e.g. self-awareness and perception, behaviour, attitudes, personality, knowledge, ability, skills, adjustment, and performance) in the IB context and the broader contexts of workplace diversity, intercultural communications and managerial psychology are worthy of further investigation.

In terms of management in Africa, it is worth acknowledging the process of China's emergence in the world's top economies and its extensive engagement in Africa. This requires both academics and practitioners to re-examine the cultural impacts of Chinese firms on African workers, while also recognising that the way Chinese firms within China have changed due to globalisation will also impact their operations in Africa. This is because the Chinese culture, especially at the organisational level and the individual level, may experience significant reform through foreign investments into China. This might involve the changes of work attitudes of Chinese employees through working in western firms in China; changes in institutions and their impact on organisational behaviour in China; and the influence of these on the way Chinese employees respond to the Confucian philosophy. Our concern is then how Chinese corporations transfer their management practices into Africa considering the changes they themselves are experiencing. The Confucian philosophy acts as an unofficial but powerful system of moral, political and social principles governing almost every aspect of Chinese life (e.g. Wang et al., 2005). Yet, the approach to management in Chinese firms has itself changed over time, absorbing a western ethos and resulting in a hybridised system. The transfer of this approach to Africa thus reflects a much more 
culturally complex system of human resource practices into an equally diverse African context which is itself a blend of indigenous and western thought.

Taking into account the cultural context, Yousfi (2014) illustrates how hybridity emerges when a US management model is imported into an African country, Tunisia. She found that the African employees resisted changes when their indigenous values were impacted by new management practices. However, to implement new practices, African workers reinterpreted them in the local cultural context, thus the transformation of these practices has involved an integration of identity construction, local power dynamics and local cultural frameworks of meaning. These culture related elements in Yousfi's (2014) work shed light on future research on how Chinese firms fit into the local cultural environment, and how the local power might shift between Chinese and African employees. In particular, with the integration of different cultures and learning, further research should seek to understand the effectiveness of the transmission of the Chinese culture and values in the process of transferring Chinese management practices into Africa. This requires for the research on the dynamics of the hybridisation, as proposed by Yousfi (2014), which is in this case based on the indigenous African culture, the Chinese culture and philosophy, and the impact of the West on China and Africa.

Some scholars argue that the success of Chinese firms in Africa may be enhanced by the shared cultural values of harmony and respect between the Confucius and the contemporary African cultural values, such as Ubuntu (see Mangaliso, 2001). On the other hand, in a recent study, Kamoche and Siebers (2014) found that Chinese managers believed that low-skilled African workers exhibited different work attitudes, and faced barriers to learning and adapting to Chinese work practices, which may be attributable to cultural differences. For these Chinese managers, African workers have a more relaxed attitude which contrasts with that of Chinese workers whose values are said to derive from a diligencerooted culture (also see Graham and Lam, 2003). The Chinese managers' interpretation, however, failed to take into account the well-established issue of the impact of a deprivation of ownership amongst African workers, and the highly targeted approach of Chinese migrant workers seeking to maximize their earnings by putting in long hours. These two realities are hard to reconcile, and result in significant challenges for cooperation and work performance. As a consequence, senior positions in Chinese firms are mostly held by Chinese nationals (see Kamoche and Siebers, 2014), who seek to introduce Chinese work practices and cultural values into the African workplace. In this regard, it is important to gain a better 
understanding of how hybrid practices, involving the cultures and values of Africa, China and the West, may lead to a transformation of management practices in African countries.

\section{Human capital development in Africa: the role of $\mathrm{HR}$ practitioners}

Central to the research and debate on Africa's development is the argument that effective development of human capital is key to realising Africa's enormous economic potential which should be the foundation for the eradication of poverty and other social challenges (Fortson, 2011; Lynham and Cunningham, 2006; Osman-Gani, 2004). However, there is inadequate recognition of the need to determine, within organisational and enterprise levels, who should play the key role of translating Africa's vision of human capital development into practice. Although scholars view human capital as the possession of knowledge, skills, and “other" human qualities (Hatch \& Dyer, 2004; Hsu et al. 2007; Schmidt and Hunter, 1998), state interventions in human capital (Barro and Lee, 1993; Rasiah, 2002) and experts on Africa's human capital development appear to concentrate on the provision of education and health (Bennell, 1996; Birdssall, \& Hamoudi, 2004; Cohen and Soto, 2007; Fortson, 2011; Glewwe and Jacoby, 1995; Nsouli, 2000; Sahn, 1992) rather than all elements that constitute human capital. As a consequence, organisations and business enterprises in Africa are left shouldering the responsibility of completing the task of developing Africa's human capital through the provision of skills, ability and "other" work-related human qualities. Given the state's concentration on the provision of education, attention must now focus on the role of organisations and business enterprises pertaining to how human capital is developed in Africa. Hence, further research is needed on how the human capital development equation and vision can be implemented at organisational and business enterprise levels.

\section{The case for HR profession in Africa's economic and social development}

HR profession is equipped to make a significant contribution to the development of human and organisational capacities that can lead to the realisation of Africa's potential. To appreciate the potential role of the HR profession, it is worth noting that the profession has grown in leaps and bounds extending beyond an administrative role into national human resource development (McLean, 2006), strategy formulation (Boxall and Purcell, 2011), and 
knowledge and talent development at both organisational and national levels (Collins and Smith, 2006). HR as a profession can now boast of satisfying all the criteria of a profession which includes: body of knowledge; code of ethics and discipline; certification, education and training; governing body; legal status; research; contribution to society; independence; and recognition (Ulrich et al., 2013).

Regarding its relevance to contributing to Africa's institutional, organisational and business enterprise challenges, the profession can also lay claim to expertise in organisational change and development, including public service reform, application of Information and Communication Technology (ICT) to provide solutions to people management issues, the development of leadership and managerial competencies, and the development of structures and systems for the implementation of good governance systems and socially responsible enterprises. It is also worth pointing out that HR professionals are well versed in the knowledge of how adults learn and acquire skills in the workplace which is vital for implementing a human capital development vision. They are also adept in diagnosing skills and learning characteristics of adults in the workplace. Given that work attitudes and values are considered as part of human capital, HR professionals' knowledge of the causes of human behaviour in the work setting will enable them to help develop the system and structures that will elicit appropriate workplace behaviour.

The case for HR professionals' role in Africa's quest for human capital development is further supported by the limitation in the current approach to human capital imperative. Although the validity of the above arguments is not in doubt, there is a lack of clear practical guidelines on how to develop the needed knowledge, skills, abilities and work-related values to ensure the realisation of Africa's potential. This neglect of the practical dimension seems to imply that the implementation of Africa's human capital vision can be undertaken without a professional foundation. We argue that the adoption of the liberal market approach to human capital development which focuses on supplying the African labour market with theory driven job-seekers devoid of other key components of human capital (i.e. skills, ability and values) will not lead to the realisation of Africa's potential. Therefore, there is an urgent need to co-opt HR professionals to be key partners to the implementation of human capital development in Africa. In a nutshell, the current approach to human capital development has opened an avenue for the HR profession and function to play critical roles by providing the intellectual platform and tools that will enable the realisation of Africa's human capital vision at organisational and business enterprise levels. 
Africa is at a stage where the role of key professions needs to be redefined within the context of "institutional void" and social and economic challenges. The HR profession has the essential theoretical and practical foundation to understand the human dimensions of economic and social challenges facing Africa, and how individuals and organisations can be supported to address them. Taking the case of HIV/AIDS as an example, HR practitioners with their background in health and safety can and do play key roles in helping the implementation of international and national policy on the disease even at societal level (Mamman et al., 2012; Mamman, and Bakuwa, 2012). HR professionals can also act as a conduit through which international and national social interventions can be implemented at the community level. Such intervention might include health and safety (Kangethe, 2005), environmental protection through its "green HRM" programmes (Berrone and Gomez-Mejia, 2009; Brio et al., 2007) and, social integration and inter-ethnic harmony through its diversity programmes (Chattopadhyay; 2003). With a strong background in the knowledge of and skills in pedagogy, curriculum development and training, HR professionals can make a significant impact on various aspects of human capital development initiative within and outside the entity which they serve.

A continent that is reported to have many ineffective organisations and institutions (Easterly and Levine, 1997; Nsouli, 2000; Wohlgemuth et al., 1998) needs the support of relevant professionals with the knowledge, skills and ability to develop and utilise the potential of its people in a systematic and professional way. Their role should be to advise, guide, and implement human capital development at institutional and organisational levels. At this critical time, Africa's human capital development intervention is too important to be left in the hands of practitioners with limited understanding of what constitute human capital, how to develop it and, how to effectively utilise it. In a nutshell, better equipped and relevant professionals are required to advise and implement a human capital-related vision at an organisational level where economic and social value is created (Nsouli, 2000; Rodrik, 1997). However, the main challenge is that we do not adequately know how Africa's human capital development vision is actually implemented. Nor do we have adequate knowledge of the key players and their competencies in the implementation. Finally, apart from national educational policies, there is hardly any literature on how Africa's vision for human capital development is translated at the organisational level. 


\section{Developing organisational competencies}

The potential role of HR professionals in the realisation of Africa's vision for human capital development has already been highlighted. To play such a role, HR professionals need to help develop human and organisational capacities for the organisation. Hence, they need to help organisations develop their own competencies. What competencies do organisations need? We adopt Lado and Wilson's (1994) categorisation of organisational competencies to illustrate where HR professionals in Africa can make a significant impact on human and organisational capacities. Lado and Wilson (1994) identified the following competencies that are required to deliver success: managerial competencies (unique capabilities of leaders to articulate vision, enact environment, and realise the vision); input-based competencies (organisational resources, particularly human resources, which enable the transformation processes to create social and economic value); output-based competencies (this is knowledge-based invisible assets such as image, reputation in quality, and customer loyalty, all of which are made possible by the decisions and actions of organisational members); transformational competencies (this relates to the capacity to transform inputs into outputs with the help of innovation, entrepreneurship, organisational learning and organisational culture).

How can African HR professionals help deliver these competencies? African HR professionals can help deliver these competencies by developing HR systems that enable the acquisitions and utilisation of the organisational competencies. For example, they can develop an HR system that enables the acquisition of managerial competencies which facilitates senior managers to create a vision for their organisations and help realise the vision (Lado and Wilson, 1994). African HR professionals need to help eradicate or replace competence-destroying HR and organisational systems which inhibit the acquisition and utilisation of organisational competencies. In a nutshell, it is almost impossible to develop the human capital needed by the African economy without developing the HR and organisational systems that allow the acquisition and utilisation of organisational competencies identified above.

To conclude this section, we argue that there is potentially a major research agenda for those interested in human capital development in Africa in general, and those interested in the role and impact of HR professionals in particular. There is a need to identify industryspecific and organisation-specific competencies that African HR professionals need to carry out their roles. Also, given the unique African business environment and the complex cultural 
context discussed above, there is a need to identify Africa-specific organisational competencies. In this respect, research is also needed to determine how African HR professionals can help realise this objective. Concurrently, organisational and HR systems that will deliver such competencies also require investigation. Given the diversity of the African socio-economic environment and multi-faceted cultures, research will also be essential to determine the degree to which the crucial competencies may vary and the reason for the variance. Correspondingly, research will be needed to establish the variation of organisational and HR systems across Africa. Below, we consider what the management of people means for workplace sustainability.

\section{Employees, organisations, and workplace sustainability}

Managing employees, as valuable human resources, remains a critical issue (Schuler and Jackson, 1987). At the centre of organisational sustainability, the need to meet employees' intrinsic and extrinsic needs which are context specific remains essential to organisations' survival and competitiveness (Kamoche et al., 2012). As organisations strive to create innovative values through human resources, the challenge remains: how can organisations foster conditions for managing human resources that are conducive to building employees' well-being, commitment and citizenship behavior in the workplace? The inability to create effective conditions for managing human resources across organisations poses serious challenges for workplace sustainability (Garavan and McGuire, 2010). In institutional environments associated with endemic social challenges such as high unemployment, poverty, and institutional voids such as those found in developing societies (e.g., see De Soto, 2000), organisations need to build conditions that spur employees' motivation to engage in sustainable and innovative work practices that contribute both to business success as well as employee well-being.

The recent literature has continued to debate how effectively organisations utilise corporate social responsibility (CSR) through the use of human resources (Garavan and McGuire, 2010; Newenham-Kahindi, 2011), and how organisations strive to instil CSRfriendly values within and outside workplaces in a sustainable manner. Due to an increasing interest in sustainable CSR and its potential contributions to business success, it has become commonplace for organisations to adopt this approach with the aim of motivating employees to be mindful of the social and eco-friendly issues at work and across communities where 
they operate (Selmier et al., forthcoming; Li et al., 2013). Often organisations would encourage employees to give back to communities through social activities and awareness training. This is due to the fact that organisations consider CSR as a powerful corporate strategy to foster business-society relationships and public image in their operations, as well as an essential business tool to develop societal trust, and secure new partners and customers (Newenham-Kahindi, 2007).

Despite its popularity, CSR remains limited to transactional (business as usual approach), philanthropic (donation) orientations (Eweje, 2006). In addition, several CSR policies and practices continue to promote western-centric convergence of global best CSR business practices which neglect specific social and institutional context issues relating to employees and external stakeholders (Newenham-Kahindi, 2011). Given the continuous challenges and the potential outcome of establishing sustainable CSR practices, there is an increasing demand for organisations to seek new ways to innovate CSR practices sustainably (Idemudia, 2009; Muthuri et al., 2012). While this approach helps to advance the interests of organisations' image and reputation, there has not been sufficient research specifically to unearth the serious challenges facing employees in the workplace and how to advance their well-being sustainably across organisations in Africa (Kamoche et al., 2012). In this editorial section, we aim to highlight the need for academics and practitioners to understand the nature of institutional conditions that are essential to influence the organisation-HR engagement nexus in a sustainable way.

For example, an obvious challenge which is common to many African employees is to secure employment and remain innovative and competitive in the workplace, followed by an inherent responsibility to support an extended family. This duty exemplifies the dominant communal/societal logic which is traditionally accepted as a more legitimate modality but also provides an example of an accepted human relations and interdependence model across societies in Africa (Mangaliso, 2001; Newenham-Kahindi, 2007; van der Colff, 2003). Despite this contextual reality, organisations inability to pursue opportunities through the management of human resources in a sustainable manner is ultimately based on their failure to acknowledge the fact that employees already know what contextual challenges they face on a daily basis and how to engage them to develop alternative employees' innovative capabilities to address these challenges. We suggest that there is an urgent need to mutually cooperate, listen, acknowledge and embrace their contextual challenges and aspirations within organisations (Kamwangamalu, 1999: 33). For example, while employees are motivated by tangible rewards such as financial rewards, the virtue of "symbiosis" 
(Mangaliso, 2001: 24) in the midst of scarcity remains strong among employees in Africa. According to Mangaliso (2001), human interdependence in Africa as seen through the Ubuntu philosophy remains paramount. The inherent characteristics of human interdependence through Ubuntu emphasise "reciprocity and the virtue of symbiosis," elegantly summed up as "a person becomes a person only through his or her relationship with and recognition by others" (24). This is a powerful force behind employees' work commitment and success in workplaces; and thus organisations that consider embracing this virtue are the ones that would sustainably balance the complex contextual issues that involve employee-organisation interactions.

We specifically argue that the virtue of symbiosis and human interdependence among many employees echoes the embedded nature of institutional logics existing in Africa. We define institutional logics as "socially constructed, historical patterns of cultural symbols and material practices, including assumptions, values, and beliefs, by which individuals and organisations provide meaning to their daily activity, organise time and space, and reproduce their lives and experiences" (Thornton et al., 2012: 2). We suggest here that institutional logics based on human interdependence and virtue of symbiosis must be understood by organisations as part of employees' 'DNA', and how they shape their actions and status within an institutional context. By embracing this contextual logic, organisations must assist employees to respond to their workplace need, and thereby meet their extrinsic and intrinsic needs which are critical to developing commitment and citizenship behaviour.

Going forward, we propose the following in relation to researchers and practitioners. While contextual issues facing employees could be numerous, sometimes ambiguous and extensive across different organisations, researchers need to acknowledge and embrace the critical role employees play in organisations, and how they can contribute towards a more effective organisational-employee interaction. Employees should be seen as a source of solutions to organisations, if a sustainable employee-organisation nexus has to be maintained. Organisations should also seek to implement knowledge, vision and experience which is deeply rooted and embedded in employees' aspirational values. Furthermore, in order to better understand employees' intrinsic and extrinsic values in an African context, researchers must consider using multiple research methods grounded in African institutional contexts rather than relying on large quantitative survey data to solve complex employees' issues.

For practitioners, we urge that African employees must be seen as new frontiers where new and dynamic innovative ideas can be cultivated and invested to help organisations and businesses alike to advance smart strategies (both macro and micro). We argue that by 
investing in an on-going mutual dialogue and joint discussion between organisations and employees, unexplored complex institutional and cultural issues facing employees can be identified and then translated into significant policy applications for human resource practices and workplace sustainability in Africa.

\section{This special issue}

This special issue is guided by an important objective: how might we as researchers begin to ask new questions that address the growing complexity of the management, cultural and organisational context in Africa? The papers presented here carry on an on-going debate but also generate new and exciting insights. The first paper by Babalola and Bruning addresses the issue of career orientation and how it impacts individuals' choice in a developing country context. With reference to Nigeria, the authors show how individuals' personality, which is constantly under the influence of external factors (globalisation and technology) and internal factors (contextual cultural dispositions and identity), impact individuals' attitude, choice, and response towards careers. They question whether the predominantly western perspective applies to an African context, and with reference to generic terms such as "protean", "boundaryless" and "locus of control" (LOC) to illustrate how career orientation continues to play out, they highlight the role of incremental implicit theory.

The paper by Gómez-Miranda et al examines the role of organisational culture and the impact of its performance on international joint ventures (IJVs) among small-medium sized Spanish-Moroccan firms. Given the complexity of IJVs, and especially between developed and emerging markets, the paper presents the significance of context and the way it moderates the role of staff in management, the degree of decision making and corporate governance. Personal relationships at all levels of IJVs are found to be paramount, if organisations are to achieve positive levels of competitiveness, efficiency and effectiveness. More importantly, the paper suggests the prerequisite of developing localisation and organisational strategies to help IJVs achieve their goals.

Newenham-Kahindi tackles the topic of sustainable development and its implications for Multinational Enterprises (MNEs), a topic which has been of interest in the social sciences. The author of this paper sought to understand how MNEs implement sustainable development initiatives in an African context. The paper uses institutional theory as a theoretical framework for understanding the relationship between MNEs and the rural 
communities in Tanzania. The paper highlights the crucial and bridging role employees and internal stakeholders can play in the implementation of CSR initiatives of MNEs in the African context. The findings have implications for MNE strategies in general and the roles of HR practitioners regarding how they can leverage their skills and competencies in enabling employees to serve as a bridge to interact with the wider community in particular.

Iwowo's paper tackles the enduring challenge of leadership and management development in Africa. The paper begins by observing that the debate has tended to be framed within a narrative of deficiency, with a preponderance on deficiency and weakness. This apt observation indeed applies to much of what constitutes management debate within the African context, where managerial expertise and management approaches are not only compared unfavourably to the mainstream, but are also explained in ways that are theoretically inadequate. Iwowo's paper seeks to broaden the theoretical space within which leadership can be understood and practised, and to that extent is a timely reminder of the need to go beyond the well-trodden path in theory development while at the same time eschewing the superficial prescription that is prone to idealise the African business and organisational context.

This special issue will hopefully generate further debate and research into the everchanging African organisational context, examining recurring themes with new and innovative analytical lenses and methodologies, and identifying ways in which real, meaningful and sustainable progress might be achieved in theory, practice and policy.

Acknowledgements: we are grateful to the scholars who kindly reviewed the papers for this special issue.

\section{References}

Akorsu, A.D. and Cooke, F.L. (2011), "Labour standards application among Chinese and Indian firms in Ghana: typical or atypical?" The International Journal of Human Resource Management, 22, 13, 2730-2748.

Baah, A. Y. and Jauch, H. eds (2009), Chinese Investments in Africa: A Labour Perspective, African Labour Research Network, Johannesburg.

Barro, Robert J. and Jong-Wha Lee (1993), "International comparisons of educational attainment “, Journal of Monetary Economics, 33(3): 363-394. 
Bennell, P. (1996), "Rates of Return to Education: does the Conventional Pattern Prevail in sub-Saharan Africa?" World Development, 24, 183-200.

Berrone, P. and Gomez-Mejia, L. (2009), "Environmental Performance and Executive Compensation: An Integrated Agency-institutional Perspective", Academy of Management Journal, 52, 1, 103-126.

Birdssall, N and Hamoudi, A (2004), AIDS and the accumulation of and utilization of human capital. In M. Haacker (ed.). The macroeconomics of HIV/AIDS. Washington DC. International Monetary Fund. 134-166.

Boxall, P. and Purcell, J (2011), Strategy and Human Resource Management, $3^{\text {rd }}$ Edition, Basingstoke: Palgrave Macmillan.

Bräutigam, D. (2011), China in Africa: What Can Western Donors Learn? Oslo: Norwegian Investment Fund for Developing Countries (Norfund).

Brio, J.A., Fernandez, E. and Junquera, B. (2007), "Management and Employee Involvement in Achieving an Environmental Action-based Competitive Advantage: An Empirical Study”, The International Journal of Human Resource Management, 18, 4, 491-522.

Chattopadhyay, P. (2003), "Can dissimilarity lead to positive outcomes? The influence of open versus closed minds", Journal of Organizational Behavior, 24, 295-312.

Cohen, D. and Soto, M. (2007), Growth and human capital: good data; good results. Journal of Economic Growth, 12, 51-76.

Collins, C.J. and Smith, K.G. (2006), "Knowledge exchange and combination: The role of human resource practices in the performance of high-technology firms", Academy of Management Journal, 49, 544-560.

De Soto, H. (2000), The mystery of capital: Why capitalism triumphs in the West and fails everywhere else, Palgrave, New York.

Easterly, W. and Levine, R. (1997), “Africa's Growth Tragedy: Policies and Ethnic Divisions", Quarterly Journal of Economics, 112, November, 1203-50.

Eweje, G. (2006), "The role of MNEs in community development initiatives in developing countries: Corporate social responsibility at work in Nigeria and South Africa", Business and Society, 45(2), 93-129.

Fortson, J.G (2011), Mortality Risk and Human Capital Investment: The Impact of HIV/Aids in Sub-Saharan Africa. The Review of Economics and Statistics, February 2011, 93(1): $1-15$.

Garavan, N. T. and McGuire, D. (2010), "Engaging Organizations in Environmental Change: A Greenprint for Action”. Advances in Developing Human Resources, 12, 5, 487-507. 
Glewwe, P. and Jacoby, H. (1995), “An economic analysis of delayed primary school enrolment in a low income country: the role of early childhood nutrition", Review of Economics and Statistics', 77, 156-169.

Gomez, E., Angwin, D., Peter, E., and Mellahi, K. (2012), 'HRM issues and outcomes in African mergers and acquisitions: a study of the Nigerian banking sector.' International Journal of Human Resource Management, 23, 14: 2874-2900.

Graham, J.L. and Lam, N.M. (2003), “The Chinese Negotiation”, Harvard Business Review, October, 1-12.

Gray, K.R., Shrestha, N.R. and Nkansah, P. (2008), "A cross-cultural perspective on management in Kenya", Journal of African Business, 9, $27-58$.

Hatch, N.W and Dyer, J.H (2004), Human Capital and Learning as a Source of Sustainable Competitive Advantage. Strategic Management Journal, 25: 11551178.

Hofstede, G. (1980), Culture's consequences: International differences in work-related values, Beverly Hills, Sage, CA.

Hofstede, G. (1983), "The Cultural Relativity of Organizational Practices and Theories", Journal of International Business Studies. 14, 2, 75-89.

Horwitz, F. (2014): 'Human resources management in multinational companies in Africa: a systematic literature review', International Journal of Human Resource

Management, DOI: 10.1080/09585192.2014.934899

Horwitz, F. (2013) 'An analysis of skills development in a transitional economy: the case of the South African labour market', International Journal of Human Resource

Management, 24: 2435-2451.

House, R.J., Hanges, P.J., Javidan, M., Dorfman, P.W. and Gupta, V. (2004), Culture, Leadership and Organization: The GLOBE Study of 62 Societies, Sage, Thousand Oaks.

Hsu, I.C; Lin, C.Y, Lawler, J.J and Wu, S (2007), Toward a Model of Organizational Human Capital Development: Preliminary Evidence from Taiwan. Asia Pacific Business Review, Vol. 13, No. 2, 251-275.

Idemudia, U. (2009), "Oil Extraction and Poverty Reduction in the Niger Delta: A Critical Examination of Partnership Initiatives", Journal of Business Ethics, 90(1): 91-116.

Jackson, T. (2012), "Postcolonialism and organizational knowledge in the wake of China's presence in Africa: interrogating South-South relations," Organization, 19, 2, 181-204. 
Jackson, T. (2013), "Reconstructuring the Indigenous in African Management Research: Implications for International Management Studies in a Globalized World", Management International Review. 53, 13-38.

Jackson, T., Amaeshi, K. and Yavuz, S. (2008), "Untangling African indigenous management: Multiple influences on the success of SMEs in Kenya", Journal of World Business, 43, 400-416.

Johnson, J.P., Lenartowicz, T. and Apud, S. (2006), "Cross-cultural competence in international business: toward a definition and a model", Journal of International Business Studies, 37, 525-543.

Kamoche, K. (2000), Sociological paradigms and human resource management: An African context. Aldershot: Ashgate.

Kamoche, K. and Siebers, L.Q. (2014). "Chinese management practices in Kenya: Toward a post-colonial critique," International Journal of Human Resource Management. DOI: 10.1080/09585192.2014.968185.

Kamoche, K. and Newenham-Kahindi, A. (2012), "HRM and knowledge appropriation: the MNC experience in Tanzania”, International Journal of Human Resource Management, 23, 2854-2873.

Kamoche, K., Chizema, A., Mellahi, K. and Newenham-Kahindi, A. (2012), "Introduction: New directions in the management of human resources in Africa", International Journal of Human Resource Management, 23, 14, 1-10.

Kamoche, K., Y.A. Debra, F.M. Horwitz and G.N. Muuka (Eds) (2004) Managing Human Resources in Africa. London: Routledge.

Kamwangamalu, N.M. (1999), "Ubuntu in South Africa: a sociolinguistic perspective to a pan-African concept", Critical Arts: South-North Cultural and Media Studies, 13, 2, 2441.

Kangethe, S. (2005), "Management Perspective of Workplace Health and Safety Practices in Kenya", African Newsletter on Occupational Health and Safety, 25, 2, 41-42.

Khayesi, J.N.O. and George, G. (2011), "When does the socio-cultural context matter? Communal orientation and entrepreneurs' resource accumulation efforts in Africa", Journal of Occupational and Organizational Psychology, 84, 471-492.

Lado, A.A and Wilson, M.C. (1994), "Human Resource Systems and Sustained Competitive Advantage: A Competency-Based Perspective", The Academy of Management Review, Vol. 19 (4), 699-727. 
Leung, K. (2009), "Never the twain shall meet? Integrating Chinese and Western management research", Management and Organization Review, 5, 121-129.

Leung, K., Bhagat, S.R., Buchan, N.R., Erez, M. and Gibson, C.B. (2005), "The dynamics of top-down-bottom-up processes across levels of culture: recent advances and their implications for future research”, Journal of International Business Studies, 36, 357378.

Li, J.T. and Tsui, A.S. (2002), "A citation analysis of management and organization research in the Chinese context: 1984 to 1999”, Asia Pacific Journal of Management, 19, 87-107.

Li, J., Newenham-Kahindi, A., Shapiro, D. \& Chen, V. (2013), “The two-tier bargaining model revisited: Theory and evidence from China's natural resource investments in Africa". Global Strategy Journal, Vol. 3 (4): 300-321.

Lynham, S. A., \& Cunningham, P. W. (2006), "National human resource development in transitioning societies in the developing world: Concepts and challenges", Advances in Developing Human Resources, 8, 1, 11-135.

Mamman, A. and Bakuwa, R. (2012), "What factors influence the adoption of workplace policies in African organisations? An exploratory study of private sector companies' adoption of workplace policies in Malawi”, Journal of General Management, 37, 3, 3960.

Mamman, A., Kamoche, K. and Bakuwa, R. (2012), "The Role of Human Resource Practitioners within a Context: Should there be a unique role for African HR Practitioners?" International Journal of Academy of Organizational Behaviour Management, 1, 1, 1-40.

Mangaliso, M.P. (2001), "Building competitive advantage from "Ubuntu": Management lessons from South Africa”, Academy of Management Executive, 15, 3, 23-35.

Marton, P. and T. Matura (2011), “The 'voracious dragon', the 'scramble' and the 'honey pot': Conceptions of conflict over Africa's natural resources", Journal of Contemporary African Studies, 29, 155-167.

McLean, G. N. (2006), "National human resource development: A focused study in transitioning societies in the developing world", Advances in Developing Human Resources, 8, 1, 3-11.

McMahon, D. (2011), “Bank: China Africa investment to jump 70\% by 2015”. Wall Street Journal, 22 February. Accessed: http://blogs.wsj.com/chinarealtime/2011/02/22/bankchina-africa-investment-to-jump-70-by-2015/. 
Muthuri, J. N., Moon, J., and Idemudia, U. (2012), “Corporate Innovation and Sustainable Community Development in Developing Countries" Business and Society, 51(3), 355381.

Newenham-Kahindi, A. (2007), The impact of global business model in a developing country: the case of managing human resources in two foreign-owned banks in Tanzania, Unpublished PhD thesis, Trinity College Dublin, Ireland.

Newenham-Kahindi, A. (2011), "A global mining corporation and local communities in Lake Victoria zone: The case of Barrick gold multinational”, Journal of Business Ethics, 99, $2,253-282$.

Newenham-Kahindi, A., Kamoche, K., Chizema, A. and Mellahi, K. (2013), Effective People Management in Africa. Houndmills, Palgrave Macmillan, Basingstoke.

Nkomo, S.M. (2011), “A postcolonial and anti-colonial reading of 'African' leadership and management in organization studies: tensions, contradictions and possibilities", Organization, 18, 3, 365-386.

Nsouli, S.M (2000), "Capacity Building in Africa: The Role of International Financial Institutions", Finance and Development, 37, 4, 1-4.

Opondo, M. (2009), “The Impact of Chinese Firms on CSR in Kenya's Garment Sector,” The International Research Network on Business, Development and Society. BDS Working Paper, 7, 1-18.

Osman-Gani, A. (2004), Human Capital Development In Singapore: An Analysis of National Policy Perspectives. Advances in Developing Human Resources Vol. 6, No. 3 276-287.

Oyebade, A.O. (2007), Culture and Custom of Angola. Greenwood Press, USA.

Ramose, M. B. (2003), The philosophy of Ubuntu and Ubuntu as a philosophy. In P.H. Coetzee and A. P. J. Roux ( $2^{\text {nd }}$ Edn.), The African philosophy reader, Routledge, New York/London, pp. 230-238.

Randall S. S. and Susan E. J. (1987), “Linking Competitive Strategies with Human Resource Management Practices". The Academy of Management Executive, Vol. 1, No. 3. pp. 207-219.

Rasiah, R (2002), Systematic coordination and human capital development: Knowledge flow in Malaysia's MNC-Driven Electronic cluster. United Nations University, Institute for Technologies, Keizer Karelplein, Maastricht, The Netherlands.

Rodrik, D. (1997), “TFPG Controversies, Institutions, and Economic Performance in East Asia”, NBER Working Paper No. 5914, Cambridge, Massachusetts: National Bureau of Economic Research. 
Sahn, David. (1992), "Public expenditures in sub-Saharan Africa during a period of economic reforms", World Development, 20, 5, 673-693.

Schmidt, F. L., and Hunter, J. E. (1998), The validity and utility of selection methods in personnel psychology: Practical and theoretical implications of 85 years of research findings. Psychological Bulletin, 124, 262-274.

Schuler, R.E. and Jackson, S.E. (1987), "Linking competitive strategies with human resource management practice", Academy of Management Executive, 1: 207-219.

Schwartz, S.H. and Bardi, A. (2001), "Value hierarchies across cultures: Taking a seminaries perspective", Journal of Cross-Cultural Psychology, 32, 268-290.

Selmier, W.T., Newenham-Kahindi, A, and Oh, Hoon, C. (forthcoming), "Understanding the words of relationships: Language as an essential tool to manage CSR in communities of place", Journal of International Business Studies.

Smith, D. J. (2013), “Cell Phones, Social Inequality, and Contemporary Culture in Nigeria”, Canadian Journal of African Studies, 40, 6, 496-523.

Southall, R. and Melber H. (2009), A new scramble for Africa? Imperialism, investment and development, University of Kwazulu-Natal Press, Pietermaritzburg.

Taylor, I. (2006), 'China's oil diplomacy in Africa.' International Affairs, 82: 937-969.

Thornton, P.H. Ocasio, W. and Lounsbury, M. (2012), The Institutional Logics Perspective: A New Approach to Culture, Structure and Process. Oxford University Press, Oxford, UK.

Ulrich, D; Younger, J; Brockbank, W; Ulrich, M (2013), "The State of the HR Profession", Human Resource Management, 52, 3, 457-471.

Valchev, V.H., Nel, J.A., Van de Vijver, F.J.R., Meiring, D., De Bruin, G.P., and Rothmann, S. (2013), "Similarities and Differences in Implicit Personality Concepts across Ethnocultural Groups in South Africa", Journal of Cross-Cultural Psychology, 44, 3, 365-388.

van der Colff, L. (2003), "Leadership lessons from the African tree", Management Decision, 41, 3: 257- 261.

Walumbwa, F.O., Avolio, B.J. and Aryee, S. (2011), "Leadership and management research in Africa: A synthesis and suggestions for future research", Journal of Occupational and Organizational Psychology, 84, 425-439.

Walumbwa, F.O., Orwa, B., Wang, P. and Lawler, J.J. (2005), “Transformational leadership, organisational commitment, and job satisfaction: A comparative study of Kenyan and 
the United States financial firms", Human Resource Development Quarterly, 16, 235256.

Wang, J., Wang, G.G., Ruona, E.A.W. and Rojewski, W.J. (2005), “Confucian Values and the Implications for IHRD”, Human Resource Development International, 8, 311-326.

Wohlgemuth, L; Carlsson, J and Kifle, H (1998), Institution building and leadership in Africa. Stockholm: Nordiska Afrikainstitutet.

Yousfi, H. (2014), "Rethinking Hybridity in Postcolonial Contexts: What changes and What Persists? The Tunisian case of Poulina's managers", Organization Studies, 35: 393-421. 